\title{
Absence of glucopenic inhibition of the insulin response to arginine at the onset of diabetes in $\mathrm{BB} / \mathrm{W}$ rats
}

\author{
I. Komiya and R.H. Unger \\ Center for Diabetes Research, University of Texas Health Science Center, the Veterans Administration Medical Center \\ and the Department of Internal Medicine, University of Texas Southwestern Medical School, Dallas, Texas, USA
}

\begin{abstract}
Summary. To determine if the inhibiting effect of glucopenia on arginine-stimulated insulin secretion is impaired at the onset of autoimmune diabetes, the insulin response to arginine was studied at 5.6 and $2.8 \mathrm{mmol} / 1$ glucose in perfused pancreata isolated from $\mathrm{BB} / \mathrm{W}$ rats on the first day of diabetes and from age-matched diabetes-prone $\mathrm{BB} / \mathrm{W}$ rats without diabetes. During glucopenia the baseline insulin secretion was reduced by more than $80 \%$ in both groups. However, the arginine-stimulated insulin response in the diabetic group was only $16.5 \%$ lower during glucopenia compared to $79.1 \%$
\end{abstract}

lower in the nondiabetic controls. Also, enhancement of the arginine-stimulated glucagon response by glucopenia was modest compared to controls. The results indicated that at the onset of this form of autoimmune diabetes the surviving B cells are, for unknown reasons, hyperresponsive to arginine and that, in contrast to the controls, this response is not inhibited by glucopenia.

Key words: Glucopenia, insulin, glucagon, arginine, diabetes, $\mathrm{BB} / \mathrm{W}$ rats, perfused pancreas.
Under normal circumstances hyperglycaemia potentiates arginine-stimulated insulin secretion and glucopenia inhibits it [1-3]. At the onset of autoimmune diabetes in $\mathrm{BB} / \mathrm{W}$ rats the potentiating effect of glucose on arginine-stimulated insulin secretion is absent [4], but it is not known if the inhibitory effect of glucopenia is also impaired. The present study was designed to determine the ability of glucopenia to inhibit argininestimulated insulin secretion at the onset of spontaneous autoimmune diabetes in $\mathrm{BB} / \mathrm{W}$ rats.

\section{Materials and methods}

Male BB/W diabetes-prone rats were obtained from the University of Massachusetts at 50 days of age and fed ad libitum under controlled lighting conditions ( $12 \mathrm{~h}$ light alternating with $12 \mathrm{~h}$ darkness). Blood glucose levels were determined daily from tail blood samples using a Beckman Glucose Analyzer II (Beckman Co., Brea, Calif, USA). Urinary glucose was measured daily by using Ketodiastix. Five rats that became diabetic were studied on the first day of diabetes (defined as a fasting blood glucose level $>11 \mathrm{mmol} / 1$ accompanied by glycosuria). On the day of the experiment the mean glucose level of the 5 rats was $13.6 \pm 0.6 \mathrm{mmol} / \mathrm{l}$ and the mean age was $88 \pm$ 3 days. Five non-diabetic diabetes-prone $\mathrm{BB} / \mathrm{W}$ rats were used as controls; their mean glucose level on the day of the experiment was $6.9 \pm 0.2 \mathrm{mmol} / \mathrm{l}$ and their mean age was $83 \pm 3$ days, which did not differ statistically from the diabetic group.

On the day of study rats were anaesthetised with $50 \mathrm{mg} / \mathrm{kg}$ sodium pentobarbital injected intraperitoneally. The pancreata were isolated and perfused by the method of Grodsky and Fanska [5], as previously described in detail [6]. The perfusate was a Krebs-Ringer bicarbonate buffer containing $5 \mathrm{mmol} / \mathrm{l}$ of pyruvate, fumarate, glutamate and $5.6 \mathrm{mmol} / 1$ glucose. The flow rate was $2.7 \mathrm{ml} / \mathrm{min}$. Follow- ing a $10-$ min equilibration period the effluent was collected in chilled tubes at 1 -min intervals. After a 10-min baseline perfusion period, $10 \mathrm{mmol} / 1$ arginine hydrochloride was perfused for $10 \mathrm{~min}$. Five minutes later the glucose concentration was lowered to $2.8 \mathrm{mmol} / 1$ and after a $10-\mathrm{min}$ baseline interval $10 \mathrm{mmol} / 1$ arginine was perfused again for $10 \mathrm{~min}$.

Insulin was measured by the method of Yalow and Berson [7] with modification [8]. Glucagon was measured by a previously described method using 30K. [9]. The integrated hormone response to given stimulus was the total of the 10 incremental values during 10 -min of stimulation.

\section{Statistical analysis}

All data were expressed as means \pm SEM. The statistical significance of difference was estimated by paired and non-paired Student's t-test.

\section{Results}

\section{Effect of glucopenia on baseline} and arginine-stimulated insulin secretion by pancreata of diabetic and nondiabetic $B B / W$ rats

Baseline insulin secretion in both $\mathrm{BB} / \mathrm{W}$ diabetic and nondiabetic rats was much lower at $2.8 \mathrm{mmol} / 1 \mathrm{glu}-$ cose than at the $5.6 \mathrm{mmol} / 1$ concentration $(p<0.001$ and $p<0.05$ respectively) (Fig. 1); the reduction in the 2 groups averaged $83.3 \pm 1.8 \%$ and $88.6 \pm 3.6 \%$ respectively. However, in the diabetic group the insulin response to $10 \mathrm{mmol} / 1$ arginine was not fully inhibited by glucopenia; in nondiabetic rats the insulin response to arginine at $2.8 \mathrm{mmol} / 1$ glucose was $20.9 \pm 4.3 \%$ of 
that at $5.6 \mathrm{mmol} / 1$ glucose $(p<0.01)$, whereas in diabetic rats it was $83.5 \pm 8.9 \%$ of the response to $5.6 \mathrm{mmol} / 1$ glucose (NS). The insulin response to arginine during glucopenia was 2 -fold greater in diabetic rats than in normal rats $(1.52 \pm 0.22 \mathrm{mU} / 10 \mathrm{~min}$ vs $0.69 \pm 0.20 \mathrm{mU} / 10 \mathrm{~min} ; p<0.05$ ) (Figs. 1 and 2).

\section{Baseline and arginine-stimulated glucagon secretion at $5.6 \mathrm{mmol} / \mathrm{l}$ or $2.8 \mathrm{mmol} / \mathrm{l}$ glucose in diabetic and nondiabetic $B B / W$ rats}

In nondiabetic rats the baseline glucagon level was not altered by the lower glucose concentration (Fig. 3). In diabetic rats it was paradoxically reduced, averaging $67.1 \pm 6.9$ percent less at $2.8 \mathrm{mmol} / 1$ glucose than at the $5.6 \mathrm{mmol} / 1$ concentration $(p<0.01)$. In the diabetic rats the glucagon response to $10 \mathrm{mmol} / 1$ arginine at

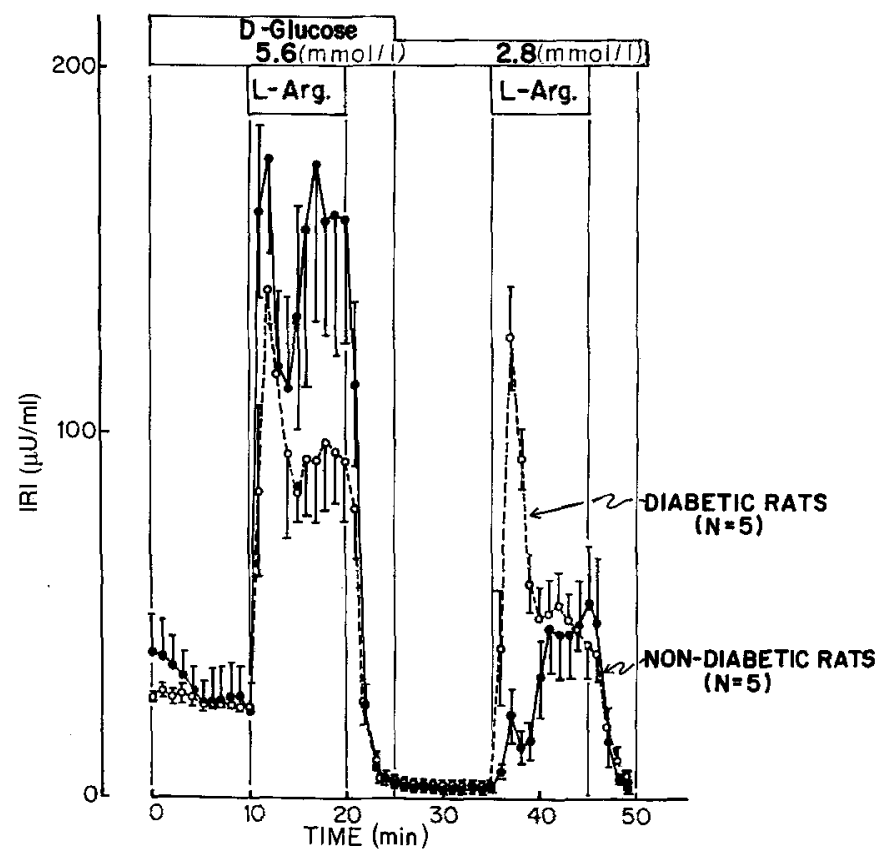

Fig. 1. The mean $( \pm S E M)$ response to arginine at normal and low glucose concentrations in the perfused pancreas of new onset diabetic $\mathrm{BB} / \mathrm{W}$ rats and age-matched nondiabetic $\mathrm{BB} / \mathrm{W}$ control rats
$5.6 \mathrm{mmol} / 1$ glucose was almost twice that of the nondiabetic rats $(23.10 \pm 2.63 \mathrm{ng} / 10 \mathrm{~min}$ vs $12.43 \pm$ $1.70 \mathrm{ng} / 10 \mathrm{~min} ; p<0.01$ ) (Figs. 2 and 3 ), but the enhancement by glucopenia was modest $(23.10 \pm$ $2.63 \mathrm{ng} / 10 \mathrm{~min}$ vs $30.53 \pm 3.94 \mathrm{ng} / 10 \mathrm{~min} ; p<0.05)$, compared to the two-fold enhancement in the nondiabetic rats $(12.43 \pm 1.70 \mathrm{ng} / 10 \mathrm{~min}$ vs $32.24 \pm$ $3.85 \mathrm{ng} / 10 \mathrm{~min} ; p<0.01)$.

\section{Discussion}

This study examines the effect of glucopenia upon baseline and arginine-induced insulin and glucagon secretion in pancreata isolated from newly diabetic BB/ $\mathrm{W}$ rats and from nondiabetic $\mathrm{BB} / \mathrm{W}$ control rats. The baseline secretion of insulin was markedly reduced by glucopenia in both groups. In the diabetic group the insulin response to arginine at the $5.6 \mathrm{mmol} / 1$ glucose concentration was as great as in the controls, thus confirming earlier work [4]. However, in the diabetic group it was only $20 \%$ lower during glucopenia, compared to $80 \%$ lower in the nondiabetic group. In fact, at the $2.8 \mathrm{mmol} / 1$ glucose concentration the arginine-induced insulin response in diabetic $\mathrm{BB} / \mathrm{W}$ rats was more than twice that of nondiabetic $\mathrm{BB} / \mathrm{W}$ controls $(p<0.05)$, despite the fact that only $20 \%$ of the normal complement of B cells are still present on the first day of diabetes [4]. Thus, both the enhancing effect of a high glucose concentration and the inhibitory effect of a low glucose concentration upon arginine-induced insulin secretion are absent at the onset of diabetes in $\mathrm{BB} / \mathrm{W}$ rats. The latter abnormality has been observed in diabetic patients [10] and in animal models of streptozotocin-induced diabetes [11], but has not been reported in spontaneous autoimmune diabetes.

The mechanism of these abnormalities is unclear. One possibility is that the ability to recognise transport and/or metabolise glucose is somehow altered in the B cells that are still present and functioning on the first day of $\mathrm{BB} / \mathrm{W}$ diabetes [12]; indeed, the glucose transport activity in the islets of $\mathrm{BB} / \mathrm{W}$ rats on the first day
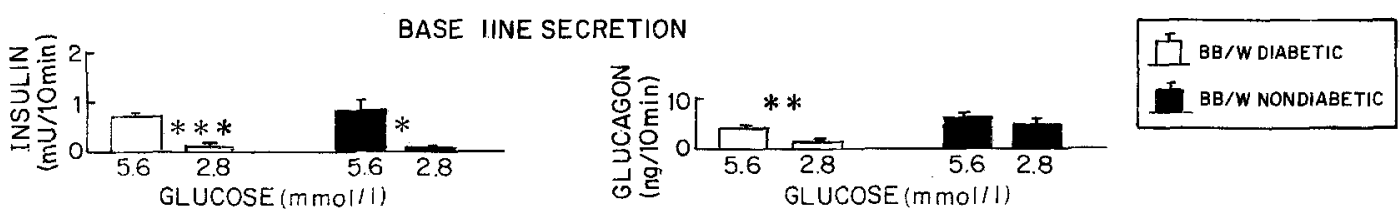

RESPONSE TO ARGININE
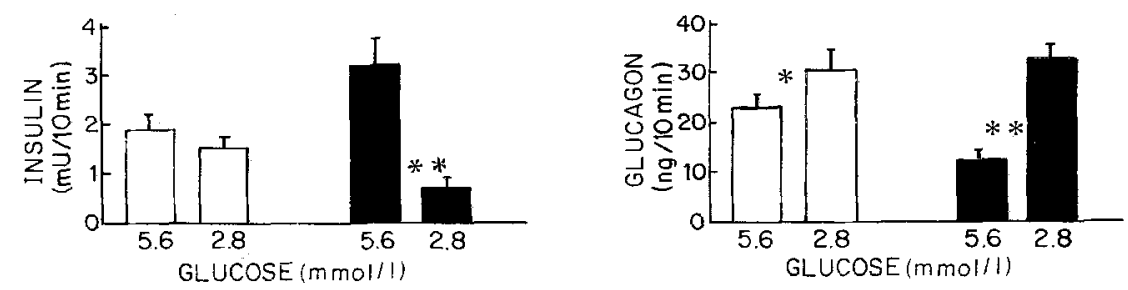

Fig. 2. Comparison of the mean ( \pm SEM) baseline insulin or glucagon levels and the mean $( \pm S E M)$ integrated insulin or glucagon response to arginine in the perfused pancreas of new onset diabetic $B B / W$ rats and age-matched nondiabetic control rats. $* p<0.05, * * p<0.01, * * * p<0.001$ 


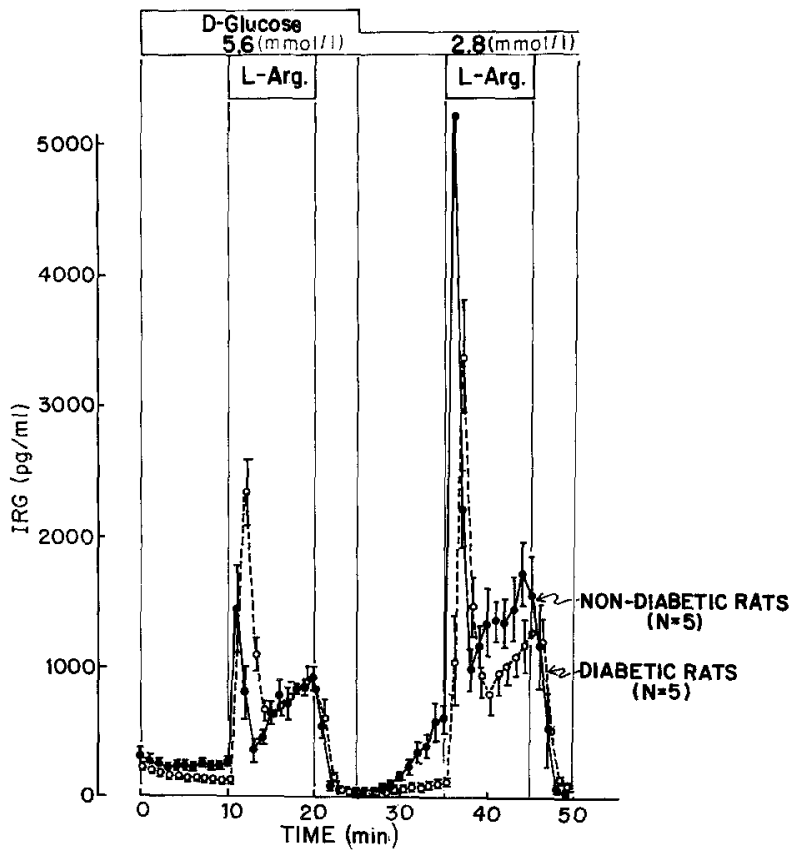

Fig. 3. The mean ( \pm SEM) glucagon response to arginine at normal and low glucose concentration in the perfused pancreas of new onset diabetic $\mathrm{BB} / \mathrm{W}$ and age-matched nondiabetic $\mathrm{BB} / \mathrm{W}$ control rats

of their diabetes has previously been reported to be markedly reduced [4]. Hyperglycaemia itself has been invoked as a reversible cause of B-cell insensitivity to glucose [13]. Yet in these studies baseline insulin secretion of diabetic pancreata was inhibited by glucopenia to the same degree as in normal ones (Fig. 2). A second possibility suggested in studies of non-insulin-dependent diabetes in adult rats following neonatal streptozotocin is that the B cells are hypersensitive to arginine [14]. A third possibility is that glucopenic inhibition of $B$ cells is mediated by nor-epinephrine released from local adrenergic nerve-endings [6] and that these anatomical relationships are disrupted by insulitis and Bcell destruction [15]. However, it has been reported that arginine-induced insulin secretion is not blocked by epinephrine [16].

The normal effect of glucopenia to enhance arginine-induced glucagon secretion [13] was also absent in the newly diabetic rats. Perhaps at the $5.6 \mathrm{mmol} / 1 \mathrm{glu}-$ cose concentration arginine-stimulated glucagon secretion was already near maximal levels, and incapable of a further increase. Alternatively, a generalised loss of glucose recognition by islet cells has been proposed to explain the impairment of certain islet cell responses to glucose in diabetes [17].

\section{References}

1. Floyd JC Jr, Fajans SS, Pek S, Thiffanet CA, Knopf RF, Conn JW (1970) Synergistic effect of essential amino acids and glucose upon insulin secretion in man. Diabetes 19:109-115
2. Efendić S, Cerasi E, Luft R (1971) Role of glucose in arginine-induced insulin release in man. Metabolism 20: 568-579

3. Pagliara AS, Stillings SN, Hover B, Martin DM, Matschinsky FM (1974) Glucose modulation of aminoacid-induced glucagon and insulin release in the isolated perfused rat pancreas. $\mathbf{J}$ Clin Invest 54: 819-832

4. Tominaga M, Komiya I, Johnson JH, Inman L, Alam T, Moltz J, Crider B, Stefan Y, Baetens D, McCorkle K, Orci L, Unger RH (1986) Loss of insulin response to glucose but not arginine during the development of autoimmune diabetes in $\mathrm{BB} / \mathrm{W}$ rats: relationships to islet volume and glucose transport rate. Proc Natl Acad Sci USA 83: 9749-9753

5. Grodsky GM, Fanska RE (1975) The in vitro perfused pancreas. Methods Enzymol 39:364-372

6. Hisatomi A, Maruyama H, Orci L, Vasko M, Unger RH (1985) Adrenergically mediated intrapancreatic control of the glucagon response to glucopenia in the isolated rat pancreas. J Clin Invest 75: $420-426$

7. Yalow RS, Berson SA (1960) Immunoassay of endogenous plas$\mathrm{ma}$ insulin in man. J Clin Invest 39: 1157-1175

8. Herbert V, Lau KS, Gottlieb CW, Bleicher SJ (1965) Coated charcoal immunoassay of insulin. J Clin Endocrinol Metab 25: 1375-1384

9. Harris V, Faloona GR, Unger RH (1979) In: Jaffe BM, Behrman HR (eds) Methods of hormone radioimmunoassay. Academic Press, New York, pp 643-656

10. Efendic S, Cerasi E, Luft R (1974) Quantitative study on the potentiating effect of arginine on glucose-induced insulin response in healthy, prediabetic, and diabetic subjects. Diabetes 23 : 161-171

11. Nesher R, Tuch B, Hage C, Levy J, Cerasi E (1984) Time-dependent inhibition of insulin release: suppression of the arginine effect by hyperglycemia. Diabetologia 26: 142-145

12. Palmer JP, Benson JW, Walter RM, Ensinck JW (1976) Argininestimulated acute phase of insulin and glucagon secretion in diabetic subjects. J Clin Invest 58: $565-570$

13. Grill V, Westberg M, Östenson C-G (1987) B cell insensitivity in a rat model of non-insulin-dependent diabetes. Evidence for a rapidly reversible effect of previous hyperglycemia. J Clin Invest 80 : 664-669

14. Giroix MH, Portha B, Kergort M, Bailbe D, Picon L (1983) Glucose insensitivity and amino-acid hypersensitivity of insulin release in rats with non-insulin-dependent diabetes: a study with the perfused pancreas. Diabetes 32: $445-451$

15. Tominaga $M$, Maruyama $H$, Vasko $M R$, Baetens $D$, Orci L, Unger RH (1987) Morphologic and functional changes in sympathetic nerve relationships with pancreatic $\alpha$-cells after destruction of $\beta$-cells in rats. Diabetes $36: 365-373$

16. Rabinowitz D, Merimee TJ, Beyess TA, Riggs L (1966) Growth hormone and insulin release after arginine: indifference to hyperglycemia and epinephrine. J Clin Endocrinol Metab 26: $1170-1177$

17. Hermansen K (1981) Pancreatic D-cell recognition of D-glucose. Studies with D-glucose, D-glyceraldehyde, dihydroxyacetone, Dmannoheptulose, D-fructose, D-galactose, and D-ribose. Diabetes $30: 203-210$

Received: 20 October 1987

and in revised form: 26 January 1988

Dr. R.H. Unger

Center for Diabetes Research

University of Texas

Southwestern Medical School

5323 Harry Hines Boulevard

Dallas, Texas 75235-9030

USA 